\title{
Exploring LPS-induced sepsis in rats and mice as a model to study potential protective effects of the nociceptin/Orphanin FQ system
}

Roisin C Thomas ${ }^{\mathrm{a}}$, Michael F Bath ${ }^{\mathrm{a}}$, Cordula M Stover ${ }^{\mathrm{b}}$, David G Lambert ${ }^{\mathrm{a}}$ and Jonathan P Thompson $^{\mathrm{a}^{*}}$

${ }^{a}$ Department of Cardiovascular Sciences, Division of Anaesthesia, Critical Care and Pain Management, University of Leicester, Robert Kilpatrick Clinical Sciences Building, Leicester Royal Infirmary, Leicester, LE1 5WW, United Kingdom.

${ }^{\mathrm{b}}$ Department of Infection, Inflammation and Immunity, University of Leicester, Medical Sciences Building, University Road, Leicester, LE1 9HN, United Kingdom.

*Prof DG Lambert and Dr JP Thompson are joint senior authors. All correspondence to Dr JP Thompson at the above address. Tel: +44 (0)116252 3132.email: jt23@le.ac.uk

Author email addresses:

RC Thomas: rct17@le.ac.uk

MF Bath:mfb11@student.le.ac.uk

CM Stover: cms13@le.ac.uk

DG Lambert: dg13@1e.ac.uk 


\begin{abstract}
The nociceptin receptor (NOP) and its ligand (N/OFQ) have been shown to exert a modulatory effect on immune cells during sepsis. We evaluated the suitability of an experimental Lipopolysaccharide (LPS)-induced sepsis model for studying changes in the nociceptin system. C57BL/6 mice BALB/c mice and Wistar rats were inoculated with different doses of LPS with or without a nociceptin receptor antagonist (UFP-101 or SB612111). In C57BL/6 mice LPS $0.85 \mathrm{mg} / \mathrm{kg}$ injection produced no septic response whereas $1.2 \mathrm{mg} / \mathrm{kg}$ produced a profound response within 5 hours. In BALB/c mice, LPS $4 \mathrm{mg} / \mathrm{kg}$ produced no response whereas $7 \mathrm{mg} / \mathrm{kg}$ resulted in a profound response within 24 hours. In Wistar rats $15 \mathrm{mg} / \mathrm{kg}$ LPS caused no septic response in $6 / 10$ animals whereas $25 \mathrm{mg} / \mathrm{kg}$ resulted in marked lethargy before 24 hours. Splenic interleukin- $1 \beta$ mRNA in BALB/c mice, and serum TNF- $\alpha$ concentrations in Wistar rats increased after LPS injection in a dosedependent manner, but were undetectable in control animals, indicating that LPS had stimulated an inflammatory reaction. IL-1 $\beta$ and TNF- $\alpha$ concentrations in LPS-treated animals were unaffected by administration of a NOP antagonist. Similarly NOP antagonists had no effect on survival or expression of mRNA for NOP or ppN/OFQ (the N/OFQ precursor) in a variety of tissues. In these animal models, the dose-response curve for LPS was too steep to allow use in survival studies and no changes in the N/OFQ system occurred within 24 hours. We conclude that LPS-inoculation in rodents is an unsuitable model for studying possible changes in the NOP-N/OFQ system in sepsis.
\end{abstract}

(250 words)

Key Words: Nociceptin; Nociceptin-orphanin FQ; Nociceptin receptor; Prepronociceptin; Sepsis; UFP-101; SB-612111.

\title{
Glossary:
}

NOP: The nociceptin receptor. G-protein coupled receptor also known as the orphanin FQ receptor. Structurally similar to opioid receptors .

N/OFQ: A 17 amino acid peptide known as nociceptin or nociceptin/orphanin FQ (N/OFQ). Endogenous ligand for the nociceptin receptor.

ppN/OFQ: Precursor protein from which N/OFQ is cleaved.

LPS: Lipopolysaccharide component of gram negative bacterial cell wall which leads to activation of immune cells.

\section{Highlights}

-We assessed the responses to different doses of lipopolysaccharide (LPS) in C57BL/6 mice, $\mathrm{BALB} / \mathrm{c}$ mice and Wistar rats.

- No symptoms of illness were observed at 24 hours with lower doses of LPS

- Higher doses of LPS produced pronounced lethargy before 24 hours.

- LPS administration had no effect on the gene expression of the nociceptin/orphanin FQ

(N/OFQ) receptor NOP and the N/OFQ receptor precursor ppN/OFQ.

- This model is not suitable to study the effects of nociceptin on septic responses 


\section{Introduction}

The nociceptin system comprises the nociceptin receptor (NOP) and its 17 amino acid peptide ligand N/OFQ, which is cleaved from a precursor protein pre-pro nociceptin (ppN/OFQ) [7]. This system has been linked to many aspects of inflammation and sepsis [10] and has been shown to modulate the cellular response to inflammatory stimuli in animals and humans [12]; in a rat caecal ligation and puncture (CLP) experimental model of sepsis, the administration of exogenous N/OFQ increased mortality whilst NOP receptor blockade significantly reduced mortality [3]. We want to establish an animal model of sepsis that is suitable to evaluate both gene expression changes in NOP and pp/N/OFQ mRNA, and the effects of nociceptin system modulation on survival. The CLP model has been criticized because of its variability within and between studies $[2,4]$. Hence we hypothesized that LPSinduced sepsis would be a suitable and reproducible model in which to study these potential changes, because by using the same dose and serotype of LPS for each experiment, the inherent variability should be reduced. The aim of these studies was to explore the responses to different doses of LPS, produce a LPS dose-response curve, and to examine the effects of a peptide ([Nphe ${ }^{1}, \mathrm{Arg}^{14}{ }^{14}$ Lys $\left.^{15}\right]$ N/OFQ-NH 2 : UFP-101) and non-peptide (SB-612111) NOP antagonist [7] on these responses. We used a peptide antagonist ([Nphe1,Arg14,Lys15] N/OFQ-NH2: UFP-101) [5] as it is widely considered to be a reference antagonist for NOP, though as a peptide there are stability issues. Hence a non-peptide NOP antagonist, SB$612111,[20]$ that is pharmacologically active in a range of behavioural assays was also included in some experiments $[14,17]$.

\section{Materials and Methods}

All experiments were performed in accordance with UK Home Office regulations (project licence number 60/4327). Animals were obtained from Charles River, UK and held in specific pathogen-free conditions in the University of Leicester's Central Research Facility for at least one week prior to commencing studies. C57BL/6 and BALB/c Mice and Wistar rats were fed (ad libitum) on PMI Lab Diet (5FL2) (BCM IPS LTD London) and allowed UV treated water at all times. Environmental enrichment was provided to all animals based on the requirements of the particular mouse/rat strain. Temperature was maintained at $21^{\circ} \mathrm{C}$ and animals were exposed to a 12 hour light, 12 hour dark cycle with a 15 minute ramp up and ramp down to simulate dusk and dawn. Mice were housed in groups of 5 per cage and rats in groups of 3. All animals were randomly allocated to experimental groups using the online Graphpad ${ }^{\circledR}$ randomizer tool [5]. All injections were administered intraperitoneally or intravenously in a volume of $100 \mu \mathrm{l}$ (mice) or $1 \mathrm{ml}$ (rats) between 9.30 and 10.30am.

The peptide NOP antagonist UFP-101 was synthesized by the group of Guerrini and Calò, (University of Ferrara, Italy), as previously described [9] and suspended in phosphate buffered saline (PBS). UFP-101 was used in similar doses to previous studies in a $\mathrm{mg} / \mathrm{kg}$ conversion dose for mice [3,6]. The non-peptide NOP antagonist SB-612111 (Tocris, UK) was dissolved in ethanol and diluted with PBS (final concentration of ethanol in $1 \mathrm{ml}$ injection $\sim 2.5 \%$ ). Lipopolysaccharide (LPS) serotype O127:B7 was purchased from Sigma-Aldrich, UK (rat studies) and LPS Serotype O111:B4 was purchased from Enzo Life Sciences (mouse studies). UFP-101 was administered via the intraperitoneal route so that it could be included together with the LPS as a single injection. SB-612111 1mg/kg was administered intravenously via the tail vein 15 minutes before the LPS inoculation. The dose and route of injection for SB-612111 has been shown to be effective in a range of behavioural assays in mice $[14,20]$. Phosphate buffered saline $\left(137 \mathrm{mM} \mathrm{NaCl}, 2.7 \mathrm{mM} \mathrm{KCl}, 10 \mathrm{mM} \mathrm{Na}_{2} \mathrm{HPO}_{4}, 2 \mathrm{mM}\right.$ 
$\mathrm{KH}_{2} \mathrm{PO}_{4}$ ) was used in controls (administered intraperitoneally where UFP-101 was used and intravenously where SB-612111 was used).

\subsection{Animal studies}

2.2.1 C57BL/6 mice. In a series of small pilot experiments the dose response to $\mathrm{mg} / \mathrm{kg}$ LPS 0.004-4 \pm UFP-101 $2 \mathrm{ng}(\sim 80 \mathrm{ng} / \mathrm{kg})$ was assessed in male and female C57BL/6 mice $(\sim 25 \mathrm{~g})$. At the end of the experiment mice were culled by cervical dislocation. $(\mathrm{n}=19)$.

2.2.2 BALB/c mice. In a second series of experiments the dose response to LPS 3, 7 or 10 $\mathrm{mg} / \mathrm{kg} \pm \mathrm{UFP}-1010.03$ or $0.3 \mathrm{mg} / \mathrm{kg}$ was assessed in male BALB/c mice $(\sim 25 \mathrm{~g})(\mathrm{n}=36)$. Mice were allocated to 3 experimental groups: A) LPS. B) LPS + UFP-101. C) PBS (control). At the end of the experiment mice were culled by cervical dislocation.

2.2.3 Wistar rats. To assess the dose response to LPS in rats, male Wistar rats $(\sim 250 \mathrm{~g})$ were administered with either LPS $15 \mathrm{mg} / \mathrm{kg} \pm \mathrm{SB}-6121111 \mathrm{mg} / \mathrm{kg}$ or LPS $25 \mathrm{mg} / \mathrm{kg} \pm \mathrm{UFP}-$ $1010.03 \mathrm{mg}(\mathrm{n}=30)$. At the end of the experiment rats were anaesthetized with isoflurane $(3 \%)$ and culled by cervical dislocation after obtaining a blood sample by cardiac puncture.

\subsection{Welfare assessment.}

Animals were monitored for responses to LPS every 30 minutes to 2 hours. All assessments were carried out blinded, by the same assessor. An in-house welfare assessment scoring system was used to score common signs of illness/disease in rodents, including piloerection, orbital tightening and lethargy. Assessments were carried out over a period of 24 hours, at the end of which animals who had not shown signs of illness in response to LPS were culled, whilst those showing signs of illness were culled upon reaching the severity limit stipulated in the project license. This was determined by the presence of a high degree of lethargy.

\subsection{Measurement of NOP and ppN/OFQ mRNA.}

2.4.1 Total RNA extraction and processing. At the end of each experiment, organs were harvested and stored at $-80^{\circ} \mathrm{C}$. The tissues taken from mice were cerebral cortex, cerebellum, brainstem, spleen, lung, heart and thymus and the tissues taken from the rats were cerebral cortex, spleen and heart. Total RNA was extracted using Tri-reagent ${ }^{\circledR}$ (Sigma-Aldrich, Dorset, UK) according to the manufacturers' instructions following homogenisation with a TissueRuptor ${ }^{\circledR}$ (QIAGEN). The concentration and purity of the mRNA was determined using a NanoDrop ND2000 spectrophotometer. Equal concentrations of mRNA from each sample were treated to remove any genomic DNA contamination with a Turbo DNA-free ${ }^{\circledR}$ kit (Life Technologies, UK).

2.4.2 Reverse transcription. Complimentary DNA (cDNA) synthesis was performed using a High Capacity cDNA Reverse Transcription Kit (Life Technologies, UK) according to the manufacturer's instructions.

2.4.3 PCR. Gene expression of NOP, ppN/OFQ, the inflammatory marker IL-1 $\beta$ and reference genes were assessed using TaqMan ${ }^{\circledR}$ probes (Life Technologies, UK). Assays were performed on the StepOne real time PCR system. Expression levels of the target genes were normalised to the endogenous reference genes $\beta$-actin (all mouse tissues), ELF1 and POP4 (rat spleen), Ywhaz and HPRT1 (rat cortex), and ELF1 and HPRT (rat heart). The expression stability of the reference genes used in the rat PCR assays was assessed by analysing the reference gene data with 2 algorithms: GeNorm [13] and Normfinder [1]. The geometric mean values of the two most stable genes in each tissue was used for normalisation. 
2.5 ELISA. To measure the extent of the inflammatory response in rats, TNF- $\alpha$ was measured in serum obtained from the blood of LPS-treated rats ( 15 or $25 \mathrm{mg} / \mathrm{kg} \mathrm{LPS})$. Analysis was performed using a DuoSet ${ }^{\circledR}$ ELISA kit (R\&D Systems, Abingdon, UK) according to the manufacturers' instructions.

\section{Results}

\subsection{Effects of LPS on survival.}

3.1.1 C57BL/6 mice. LPS at a dose of $0.85 \mathrm{mg} / \mathrm{kg}$ did not produce a septic response whereas an increase in dose to $1.2 \mathrm{mg} / \mathrm{kg}$ resulted in all animals reaching the welfare severity limit before 5 hours (Fig. 1A). This dose response was too steep to allow use in survival studies and there was a suggestion of strain differences [11] so we changed to use BALB/c mice.

3.1.2 BALB/c mice. $4 \mathrm{mg} / \mathrm{kg}$ LPS ( \pm UFP-101) did not produce a septic response. Doses of $7 \mathrm{mg} / \mathrm{kg}$ and $10 \mathrm{mg} / \mathrm{kg}$ ( \pm 0.03 or $3 \mathrm{mg} / \mathrm{kg}$ UFP-101) produced severe responses such that the severity limit was reached before 24 hours. No differences were noted in survival times between LPS-treated and LPS + UFP-101-treated groups (Fig. 1B). Therefore we abandoned using mouse as a species to use rats instead.

3.1.3 Wistar rats. Administration of $15 \mathrm{mg} / \mathrm{kg}$ LPS did not produce a septic response in 3 out of 5 treated rats and in 3 out of 5 LPS + SB- 612111 treated rats. A dose of $25 \mathrm{mg} / \mathrm{kg}$ LPS $\pm 0.03 \mathrm{mg} / \mathrm{kg}$ UFP-101 resulted in 10/10 rats reaching the severity limit by 12 hours. There was no difference in the survival times between groups that had received LPS alone and groups that had received LPS + a NOP antagonist (Fig. 1D)

\subsection{Effects of LPS on inflammatory cytokine levels}

3.2.1 IL-1及. To assess the extent of the inflammatory response to LPS, IL-1 $\beta$ mRNA concentrations were measured in the spleen of BALB/c mice by qPCR. In the LPS-treated groups (relative to control animals), there were median fold changes of 1.05 after $4 \mathrm{mg} / \mathrm{kg}$ LPS, $1.90-2.12$ after $7 \mathrm{mg} / \mathrm{kg}$, (in the in the two studies where this dose was used) and 25.83 after $10 \mathrm{mg} / \mathrm{kg}$ LPS. (Fig. 1C)

3.2.2 TNF- $\alpha$. There was a significant increase in TNF- $\alpha$ concentrations compared to controls after $25 \mathrm{mg} / \mathrm{kg}$ LPS injection. The low number of rats that responded to LPS at a dose of 15 $\mathrm{mg} / \mathrm{kg}$ meant that although an increase in TNF- $\alpha$ concentration was observed in rats that reached the severity limit, the difference was not statistically significant compared to controls. No significant differences occurred between groups that had received LPS alone and groups that had received LPS + a NOP antagonist at either dose of LPS (Table 1).

3.3 PCR. NOP and ppN/OFQ mRNA was detected in the cerebral cortex of Wistar rats. $\mathrm{ppN} / \mathrm{OFQ}$ was detected in the heart and spleen but NOP was undetected in these tissues (Table 1). NOP and ppN/OFQ mRNA was detected in the cerebral cortex, brain stem and cerebellum of all mice, whereas the remaining tissues showed very low/no expression (data not shown). No significant differences in expression of NOP or ppN/OFQ mRNA between groups were observed.

\section{Discussion}

In these studies, the administration of LPS in C57BL/6 mice, BALB/c mice and Wistar rats produced a steep dose-response curve so that at lower doses animals showed little or no signs of illness 24 hours after treatment, but at higher doses the animals reached the predetermined severity limit determined by our project licence before 24 hours had passed. Increases in proinflammatory cytokine concentrations confirm that an inflammatory response was produced 
in LPS-treated animals; however administration of LPS had no effect on the gene expression of NOP and ppN/OFQ. One reason for this could be that the changes that occur in the nociceptin system are occurring at a time after the animals in our experiments have reached the severity limit. In vitro LPS-treated splenocytes show a significant increase in N/OFQ secretion compared to controls at 24 hours after stimulation [8] and unpublished in vitro work from our lab found upregulation of ppN/OFQ mRNA in a precursor eosinophilic cell line did not occur until 48 hours post LPS-treatment. A recent study using a CLP model of sepsis in rats found increased pp N/OFQ mRNA at 72 hours, and the authors suggested that a model of 5-7 days might be required [11]. Another reason for a lack of response in the nociceptin system could be that LPS-induced sepsis does not activate the relevant pathways or transcription factors involved in upregulation of NOP and ppN/OFQ transcripts. Furthermore, the use of LPS as a model has been criticised for failing to reproduce physiological events that occur in human sepsis [9] and is therefore not considered as clinically relevant as other models. For these reasons, we recommend that in vivo research into the nociceptin system during sepsis employs the use of a longer term polymicrobial model of sepsis. Our future plan is to evaluate a model which induces sepsis via intraperitoneal injection of a faecal slurry as this has been proposed as a more reliable and reproducible model than CLP [4].

\section{Acknowledgements}

This work was funded entirely from within our Department, with no external funding. 


\section{References}

[1] Andersen CL, Jensen JL, Ørntoft TF. Normalization of real-time quantitative reverse transcription-PCR data: a model-based variance estimation approach to identify genes suited for normalization, applied to bladder and colon cancer data sets. Cancer Res. 2004;64:52455250

[2] Brookes ZL, Stedman EN, Brown NJ, Hebbes CP, Guerrini R, Calo G et al. The nociceptin/orphanin FQ receptor antagonist UFP-101 reduces microvascular inflammation to lipopolysaccharide in vivo. PLoS One. 2013;8:e74943

[3] Brookes ZL, Stedman EN, Guerrini R, Lawton BK, Calo G, Lambert DG.

Proinflammatory and vasodilator effects of nociceptin/orphanin FQ in the rat mesenteric microcirculation are mediated by histamine. Am J Physiol Heart Circ Physiol. 2007;293:H2977-85

[4] Buras JA, Holzmann B, Sitkovsky M. Animal models of sepsis: setting the stage. Nat Rev Drug Discov. 2005;4:854-65

[5] Calo G, Rizzi A, Rizzi D, Bigoni R, Guerrini R, Marzola G et al.

[Nphe1,Arg14,Lys15]nociceptin-NH2, a novel potent and selective antagonist of the nociceptin/orphanin FQ receptor. Br J Pharmacol. 2002 ;136:303-11

[6] Carvalho D, Petronilho F, Vuolo F, Machado RA, Constantino L, Guerrini R, et al. The nociceptin/orphanin FQ-NOP receptor antagonist effects on an animal model of sepsis.

Intensive Care Med. 2008;34:2284-90.

[7] Gonnert FA, Recknagel P, Seidel M, Jbeily N, Dahlke K, Bockmeyer CL, et al.

Characteristics of clinical sepsis reflected in a reliable and reproducible rodent sepsis model.

J Surg Res. 2011;170:e123-34

[8] GraphPad QuickCalcs. http://www.graphpad.com/quickcalcs/randMenu/

[9] Guerrini R, Calo' G, Rizzi A, Bianchi C, Lazarus LH, Salvadori S, et al. Address and message sequences for the nociceptin receptor: a structure-activity study of nociceptin-(113)-peptide amide. J Med Chem. 1997;40:1789-93.

[11] Shen DF, Buggage RR, Eng HC, Chan C-C. Cytokine gene expression in different strains of mice with endotoxin-induced uveitis (EIU). Ocul. Immunol. Inflamm. 2000;8:221225

[12] Thompson JP, Serrano-Gomez A, McDonald J, Ladak N, Bowrey S, Lambert DG. The Nociceptin/Orphanin FQ System Is Modulated in Patients Admitted to ICU with Sepsis and after Cardiopulmonary Bypass. PLoS One. 2013;8:e76682

[13] Vandesompele J, De Preter K, Pattyn F, Poppe B, Van Roy N, De Paepe A, et al.

Accurate normalization of real-time quantitative RT-PCR data by geometric averaging of multiple internal control genes. Genome Biol. 2002;3:research0034. 
Table 1. ELISA and $q P C R$ results. A) TNF- $\alpha$ concentrations in serum obtained from rats treated with either $15 \mathrm{mg} / \mathrm{kg}$ or $25 \mathrm{mg} / \mathrm{kg}$ LPS \pm a NOP antagonist (controls received saline) $\mathrm{n}=5$ per group. ${ }^{*}$ There was a significant increase in TNF- $\alpha$ concentration in the LPS-treated group relative to the control group, $\mathrm{p}<0.05$. Data expressed as median (range). B) qPCR of NOP and ppN/OFQ in cortex, spleen and heart of Wistar rats. Ct values for two reference genes, (geometric mean calculated), and the genes of interest were detected. Median $\Delta \mathrm{Ct}$ values (and range) for each group are shown. $\mathrm{ND}=$ Not determined.

\begin{tabular}{|c|c|c|c|c|c|}
\hline & & Control (saline) & LPS & $\begin{array}{l}\text { LPS } \\
+ \text { UFP-101 }\end{array}$ & $\begin{array}{l}\text { LPS + } \\
\text { SB-612111 }\end{array}$ \\
\hline \multicolumn{6}{|c|}{ А) TNF- $\alpha(\mathrm{pg} / \mathrm{ml})$} \\
\hline $15 \mathrm{mg} / \mathrm{kg} \mathrm{LPS}$ & & $0(0,0)$ & $0(0-441.7) \quad \mathrm{ND}$ & $\mathrm{ND}$ & $0(0-131.2)$ \\
\hline $25 \mathrm{mg} / \mathrm{kg} \mathrm{LPS}$ & & $0(0,0)$ & *223.2 (0-3978.0) & $350.1(41.1-3397.0)$ & ND \\
\hline \multicolumn{6}{|l|}{ B) $\operatorname{PCR}(\Delta C t)$} \\
\hline Cortex & NOP & $6.77(6.54-6.92)$ & $6.61(5.87-6.66)$ & ND & $6.21(6.08-7.00)$ \\
\hline (15 mg/kg LPS) & $\mathrm{ppN} / \mathrm{OFQ}$ & $7.89(7.55-8.33)$ & $7.75(7.52-8.12)$ & ND & $7.70(6.96-8.13)$ \\
\hline \multirow{2}{*}{$\begin{array}{l}\text { Cortex } \\
(25 \mathrm{mg} / \mathrm{kg} \text { LPS })\end{array}$} & NOP & $9.14(8.83-9.33)$ & $8.60(8.00-9.25)$ & $8.54(8.44-8.84)$ & ND \\
\hline & $\mathrm{ppN} / \mathrm{OFQ}$ & $7.89(7.55-8.33)$ & $7.75(7.52-8.12)$ & $7.70(6.96-8.13)$ & ND \\
\hline \multirow{2}{*}{$\begin{array}{l}\text { Spleen } \\
(15 \mathrm{mg} / \mathrm{kg} \text { LPS })\end{array}$} & NOP & $12.98(12.62-14.09)$ & $14.94(14.66-16.30)$ & ND & $14.64(13.95-16.71)$ \\
\hline & $\mathrm{ppN} / \mathrm{OFQ}$ & $10.64(8.41-11.47)$ & $10.11(8.92-10.35)$ & ND & $9.61(7.62-10.10)$ \\
\hline \multirow{2}{*}{$\begin{array}{l}\text { Spleen } \\
(25 \mathrm{mg} / \mathrm{kg} \mathrm{LPS})\end{array}$} & NOP & Undetected & Undetected & Undetected & ND \\
\hline & $\mathrm{ppN} / \mathrm{OFQ}$ & $10.52(10.25-11.36)$ & $9.90(9.17-12.47)$ & $10.42(9.78-11.24)$ & ND \\
\hline \multirow{2}{*}{$\begin{array}{l}\text { Heart } \\
(15 \mathrm{mg} / \mathrm{kg} \text { LPS })\end{array}$} & NOP & Undetected & Undetected & ND & Undetected \\
\hline & $\mathrm{ppN} / \mathrm{OFQ}$ & $7.22(6.61-9.13)$ & $6.73(6.48-8.91)$ & ND & $8.46(7.15-9.09)$ \\
\hline \multirow{2}{*}{$\begin{array}{l}\text { Heart } \\
(25 \mathrm{mg} / \mathrm{kg} \mathrm{LPS})\end{array}$} & NOP & Undetected & Undetected & Undetected & ND \\
\hline & $\mathrm{ppN} / \mathrm{OFQ}$ & $9.07(7.85-9.55)$ & $8.83(7.48-10.43)$ & $7.61(5.85-9.17)$ & ND \\
\hline
\end{tabular}


Figure. Effects of LPS on Survival and Interleukin-1 $\beta$ in Mice and Rats.

A) Survival of C57BL/6 mice following administration of $0.004-4 \mathrm{mg} / \mathrm{kg}$ LPS $\pm 2 \mathrm{ng}$ UFP-101. (UFP-101 treatment made no difference to survival so is not represented as a separate group). B) Survival of BALB/c mice following administration of 4$10 \mathrm{mg} / \mathrm{kg}$ LPS and $0.03-0.3 \mathrm{mg} / \mathrm{kg}$ UFP-101. C) Levels of IL- $1 \beta$ in the spleen of LPS treated BALB/c mice. (7mg/kg (1) and (2) refer to two separate experiments). Median and range shown $(\mathrm{n}=3)$. D) Survival of Wistar rats following administration of 15 $\mathrm{mg} / \mathrm{kg} \pm 1 \mathrm{mg} / \mathrm{kg} \mathrm{SB}-612111$ (first 3 columns) and $25 \mathrm{mg} / \mathrm{kg} \mathrm{LPS} \pm 0.03 \mathrm{mg} / \mathrm{kg} \mathrm{UFP-}$ 101. Data expressed as median (range).
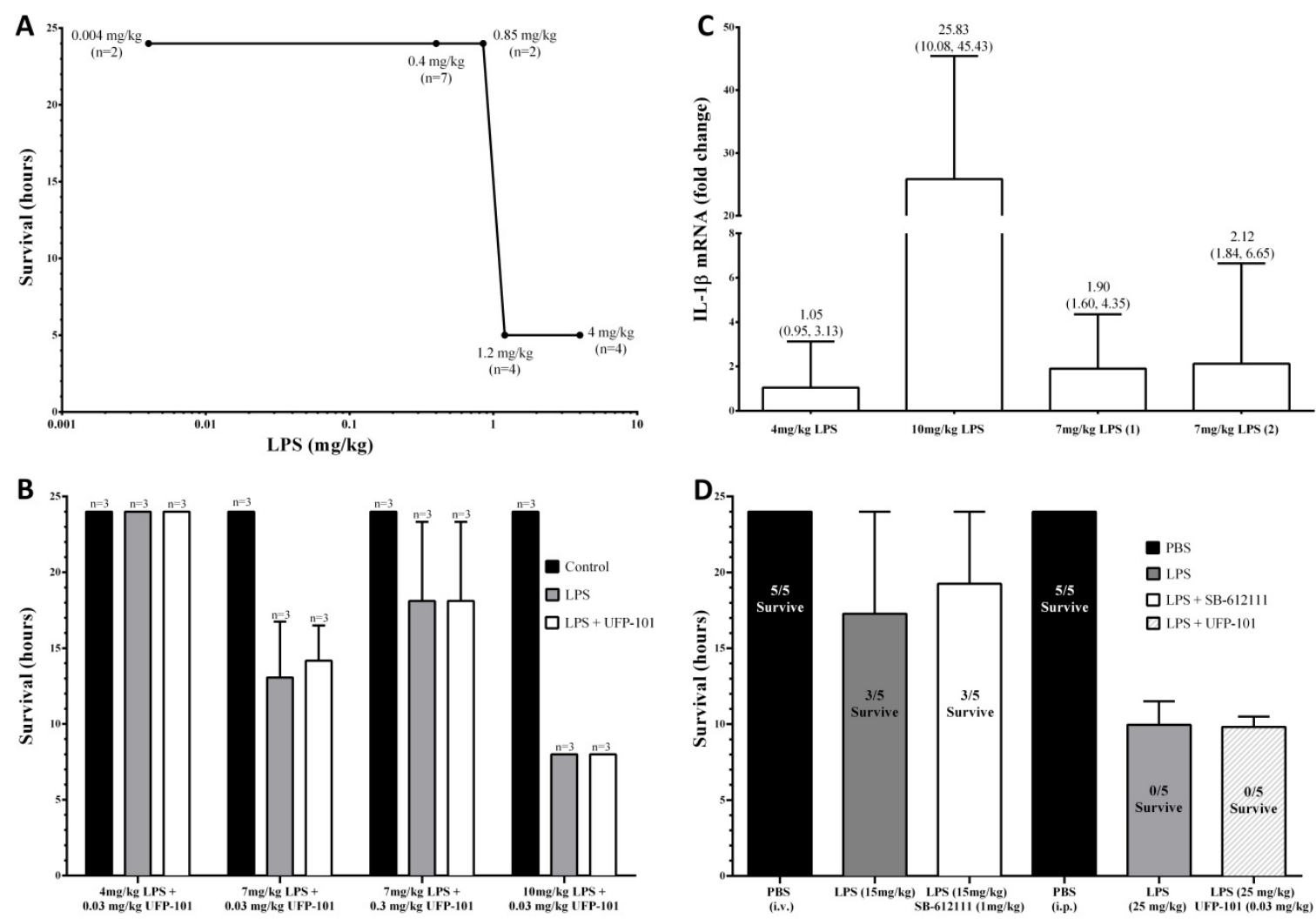